\title{
PRKAR1A/RET Fusion Protein
}

National Cancer Institute

\section{Source}

National Cancer Institute. PRKAR1A/RET Fusion Protein. NCI Thesaurus. Code C99846.

A fusion protein encoded by the PRKAR1A/RET fusion gene. This protein is comprised of approximately $240 \mathrm{~N}$-terminal amino acids of the CAMP-dependent protein kinase type Ialpha regulatory subunit protein, including a dimerization domain, fused with most of the C-terminal cytoplasmic domain of the proto-oncogene tyrosine-protein kinase receptor Ret protein, including the tyrosine kinase domain. 